[Bull. Agr. Chem. Soc. Japan, Vol. 24, No. 2, p. 211 216, 1960]

\title{
Metabolism of Aromatic Compounds by Microbes
}

\author{
Part VI. Existence of Two Pathways, the Pathway via Protocatechuic Acid \\ and the One via Gentisic Acid, in the Metabolism of \\ $m$-Hydroxybenzoic Acid by Bacteria
}

\author{
By Sin-ich Sugryama, Keiji Yano, Kazuo Komagata, \\ Masaji Kazama and Kei Arima \\ Department of Agricultural Chemistry, Faculty of Agriculture, University of Tokyo \\ Received July 11, 1959
}

\begin{abstract}
The metabolic products of $m$-hydroxybenzoic acid formed by certain Pseudomonas, Micrococcus, and Bacterium strains which possess oxidizing ability of this acid were detected by paperchromatography. It was recognized that protocatechuic acid or gentisic acid are intermediary metabolites of $m$-hydroxybenzoic acid by these bacteria and the both acids are not detected in one cultural broth.
\end{abstract}

The authors reported the metabolic pathways of $m$-hydroxybenzoic acid by various bacteria using the technique of sequential induction method and presumed that this acid was metabolized either via gentistic acid (2,5-dihydroxybenzoic acid) or via protocatechuic acid (3,4,dihydroxybenzoic acid) ${ }^{1}$.

In the previous reports, details in concern of the factors infulencing adaptive formation of the enzymes which oxidatively split $m$-hydroxybenzoic acid ( $m$-HBA) and gentisic acid (GA) by Pseudomonas ovalis S-5 have been described ${ }^{2,3)}$. On the metabolism of $m$-HBA by microbes, N. Walker") and B.S. Roof et al. ${ }^{5)}$ reported on their experiments conducted on specificities and strength of metabolic activities of several bacterial strains on this acid. However, the metabolic pathway of $m$-hydroxybenzoic acid has so far not been elucidated.

1) K. Arima, K. Komagata and N. Minoda, J. Agr. Chem. Soc. Japan, 28, 629 (1954).

2) K. Arima, K. Komagata, S. Sugiyama, M. Kazama and K. Yano, This Bulletin, 19, 51 (1955).

3) K. Arima, K. Komagata, M. Kazama, S. Sugiyama and K. Yano, This Bulletin, 19, 61 (1955).

4) N. Walker and W.C. Evans, Biochem. J., 52, proc. XXXIII (1952).

5) B.S. Roof, T. J. Lannon and J. Turner, Proc. Sor. Expt. Biol. Med.. 84, 38 (1953).
In this report detection of the metabolic products of $m$-HBA by the fifteen strains of bacteria which possess oxidizing ability of this acid by paperchromatography is described.

\section{EXPERIMENTS}

Biological: Fifteen strains of $m$-HBA metabolizing bacteria which were identified taxonomically in the previous report ${ }^{(6)}$ were used.

Method of culture: Stationary or shaking culture at $30^{\circ} \mathrm{C}$ were made on synthetic medium containing $m$ HBA as the sole carbon source. Stationary culture was carried out in $1,000 \mathrm{ml}$ of the medium in a $2,500 \mathrm{ml}$ Fernbach flask and the cells were harvested after 4 days. Shaking culture was carried out in $100 \mathrm{ml}$ of the medium in a $500 \mathrm{ml}$ Sakaguchi flask using reciprocal shaker $(130 \sim 140$ r. p. m. $7 \mathrm{~cm})$ and the cells were harvested after $16 \sim 18$ hours.

\section{Cultural medium.}

Nitrogen source: As nitrogen source, three compounds such as $\left(\mathrm{NH}_{4}\right)_{2} \mathrm{SO}_{4}, \mathrm{NH}_{4} \mathrm{NO}_{3}$ and $\left(\mathrm{NH}_{4}\right) \mathrm{H}_{2} \mathrm{PO}_{4}$, were tested for the accumulation of gentisic acid and protocatechuic acid and were proved to have no difference.

Influence of $\mathrm{pH}$ : Three levels of initial $\mathrm{pH}$ value such as $5.2,7.2$ and 8.5 were examined, and as shown

6) K. Arima, K. Konagata, S. Sugiyama and M. Kazama. f. Agr. Chem. Soc. Japan, 28, 635 (1954). 
Table I. The EFFect of pH ON PRODUCTION of Gentisic ACID or Protocatechuic Acid by Several Bacteria.

$\mathrm{pH}$ value

Detection

\begin{tabular}{|c|c|c|c|c|c|c|}
\hline \multirow{3}{*}{$\begin{array}{c}\text { Micrococcus ureae } \\
\text { S }-4\end{array}$} & \multicolumn{2}{|r|}{$\mathrm{pH}$ value } & \multicolumn{4}{|c|}{ Detection } \\
\hline & Start. & After culture & U.V. ray* & $\mathrm{FeCl}_{3}$ & $\begin{array}{l}\text { Diazo- } \\
\text { reaction }\end{array}$ & Pathway** \\
\hline & $\begin{array}{l}5.2 \\
7.2 \\
8.5\end{array}$ & $\begin{array}{l}5.2 \\
7.2 \\
7.8\end{array}$ & $\begin{array}{l}+ \\
+\end{array}$ & $\begin{array}{l}- \\
-\end{array}$ & $\begin{array}{l}+ \\
+\end{array}$ & $G$ \\
\hline Ps. avalis $\mathrm{S}-5$ & $\begin{array}{l}5.2 \\
7.2 \\
8.5\end{array}$ & $\begin{array}{l}5.4 \\
7.2 \\
8.0\end{array}$ & 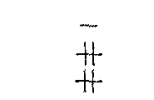 & - & $\begin{array}{l}+ \\
+ \\
+\end{array}$ & G \\
\hline Bact. sp. Ca-1 & $\begin{array}{l}5.2 \\
7.2 \\
8.5\end{array}$ & $\begin{array}{l}5.4 \\
6.6 \\
7.6\end{array}$ & \pm & - & $\begin{array}{l}+ \\
+ \\
+\end{array}$ & G \\
\hline $\begin{array}{l}\text { Ps. cruciviae } \\
\mathrm{P}-8-2\end{array}$ & $\begin{array}{l}5.2 \\
7.2 \\
8.5\end{array}$ & $\begin{array}{l}5.6 \\
7.0 \\
7.6\end{array}$ & $\overline{-}$ & $\begin{array}{l}+ \\
\pm \\
\pm\end{array}$ & $\frac{ \pm}{ \pm}$ & $\mathbf{P}$ \\
\hline $\begin{array}{l}\text { Ps. dacunhae } \\
\mathrm{R}-10-2\end{array}$ & $\begin{array}{l}5.2 \\
7.2 \\
8.5\end{array}$ & $\begin{array}{l}5.4 \\
6.6 \\
7.8\end{array}$ & $\begin{array}{l}- \\
-\end{array}$ & \pm & $\begin{array}{l}+ \\
+ \\
+\end{array}$ & $\mathrm{P}$ \\
\hline $\begin{array}{l}\text { Ps. dacunhae } \\
\text { G1-7 }\end{array}$ & $\begin{array}{l}5.2 \\
7.2 \\
8.5\end{array}$ & $\begin{array}{l}5.6 \\
6.6 \\
7.8\end{array}$ & - & + & $\begin{array}{l}+ \\
+ \\
+\end{array}$ & $\mathbf{P}$ \\
\hline
\end{tabular}

in Table I, pH 7.2 was proved to be best for the accumulation of GA. The composition of the synthetic medium which will be used in this experiment is as follows;

$\begin{array}{ccc}m \text {-hydroxybenzoic acid } & 0.5 \text { per cent } \\ \left(\mathrm{NH}_{4}\right)_{2} \mathrm{SO}_{4} & 0.1 & \prime \prime \\ \mathrm{MgSO}_{4} \cdot 7 \mathrm{H}_{3} \mathrm{O} & 0.15 & \prime \prime \\ \mathrm{KH}_{2} \mathrm{PO}_{4} & 0.1 & \prime \prime \\ \mathrm{pH}_{4} \ldots \ldots \ldots \ldots .2 & \end{array}$

Preparation of samples for chromatography from cultural broth.

The procedure is as follows;

$$
1,000 \mathrm{ml} \text { cultural broth }
$$

centrifugation at 3,000 t.p.m. 30 min. concentration in vacuum to $50 \mathrm{ml}$ : acidified by $\mathrm{H}_{2} \mathrm{SO}_{4}$

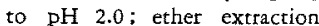
(cold) by a separation funnel, 3 times

Extraction by cold ether Residual aqueous solution (Fraction 1)

continuous hot ether extraction for 40 hours

Fraction of hot ether extraction Residue (Fraction 2)

Addition of 2,4-dinitrophenylhydrazine (Fraction 3)
Preparation of samples of chromatography from incubation mixture.

The bacteria were cultured on bouillon-peptone broth which contained 1 per cent $m-H B A$, and was harvested by centrifugation after 18 hours. Ten $\mathrm{g}$ of the wet cells were suspended in $100 \mathrm{ml}$ of $\mathrm{M} / 15$ phosphate buffer at $\mathrm{pH} 7.2$ with $300 \mathrm{mg} \mathrm{GA}$ or PCA, and were incubated at $30^{\circ} \mathrm{C}$ on the shaker. Sampling was carried out at an interval of each 2 hours, and the production of ketoacids were examined as their 2,4-dinitrophenylhydrazone.

\section{Paperchromatography.}

a) Filterpaper: The Tôyô filterpaper No. $50(2 \times 40$ $\mathrm{cm}$ ). Before development, filterpaper was saturated beforehand by the vapor of developing solvent in order to prevent the tailing of samples.

b) Developing solvents: After a survey was made for the purpose of detection of various intermediates, the following developing solvents were used;

1) Benzene: Acetic acid: Water $(2: 2: 1)^{7}$

2) Butanol; Ethanol: $\left(\mathrm{NH}_{4}\right)_{2} \mathrm{CO}_{3} \cdot \mathrm{NH}_{4} \mathrm{OH}$ buffer $(4: 1: 2)^{8,0)}$

7) H. G. Bray, W. U. Thorpe and K. White, Biocbem. J., 46. 271 (1951).

8) D. Cavalini, N. Frontali and G. Toschi, Nature, 163, 568 (1946) .

9) M. E. Fewster and D. H. Hall, Nature, 168, 78 '(1951). 
3) 3 per cent $\mathrm{NH}_{4} \mathrm{OH}$ saturated butanol

4) Butanol: Formic acid: Water (4:1.5:1)

The solvents 1) and 2) were generally used for development of the aromatic compounds. The solvents 2) and 3) for development of 2,4-dinitrophenylhydrazone of keto acids, and the solvent 4) for fatty acids. Each solvent was applied from the mixing after 3 to 4 days.

c) Development was carried out at $20^{\circ} \mathrm{C}$ by the ascending method.

d) Detection of compounds: The indicators to detect each compound are follows;

1. $m$-hydroxydenzoic acid: the diazo reaction was used.

The first solution; 1 per cent p-aminoacetophenone in $1 \mathrm{~N} \mathrm{H}_{2} \mathrm{SO}_{4}$

The second solution; $1 \mathrm{~N} \mathrm{HNO}_{2}$

After the developed papers were dried at room temperature, the first and then the second solution were sprayed and the reddish orange spots appeared.

2. Gentisic acid: This was detected by the blue fluorescence when the paper was exposed in ultra violet rays in the dark room or by the brown spots by reaction with $\mathrm{FeCl}_{3}$ (1 per cent $\mathrm{FeCl}_{3}$ alcoholic solution was sprayed). Among these, the most convenient and sensitive indicator was found to be its own blue fluorescence.

3. Protocatechuic acid: The detection of the acid was either due to the diazo reaction similar to the case of $m$ - $\mathrm{HBA}$, or due to its dark green spot by reaction with $\mathrm{FeCl}_{3}$. Usually, the dark green spot by spraying $\mathrm{FeCl}_{3}$ was used.

4. Other phenolic compounds: These were mainly detected by the reaction with $\mathrm{FeCl}_{3}$, and when the coloration was weak, alkalic solution was used as the indicator. Salicylic acid has a specific fluorescence under the ultra violet rays, and was detected by such characteristics.

5. Keto acids: The detection of keto acid was due to yellow spots of their 2,4-dinitrophenylhydrazone.

6. Aliphatic acids: After development, the paper was put in a drier at $110^{\circ} \mathrm{C}$ for 10 min. Then bromcresolpurpule solution $(0.16$ per cent in 5 per cent alcohol adjusted to $\mathrm{pH}$ 8.0) was sprayed and yellow spots were revealed on the blue back ground.

\section{RESULTS}

$\boldsymbol{R}_{F}$ values of several related compounds.

$R_{F}$ values of various phenolic acid and several other acids which were related with the terminal oxidants of these acids were estimated by different solvents. Table II shows the $R_{F}$ values
TABLE II. RF VALUeS OF THE RELATED COMPOUNDS OF MONOHYDROXYBENZOIC ACIDS WITH VARIOUS SOLVENTS

\begin{tabular}{|c|c|c|c|c|}
\hline & $\begin{array}{c}\text { Solvent } \\
\text { I }\end{array}$ & II & III & IV \\
\hline $\begin{array}{l}\text { o-hydroxybenzoic acid } \\
m \text {-hydroxybenzoic acid } \\
\text { p-hydroxybenzoic acid } \\
2,3 \text {-dihydroxybenzoic acid } \\
\beta \text {-resorcilic acid } \\
\text { protocatechuic acid } \\
\text { gentisic acid } \\
\text { catechol } \\
\text { resorcine } \\
\text { hydroquinone }\end{array}$ & $\begin{array}{l}0.81 \\
0.55 \\
0.72 \\
0.40 \\
0.27 \\
0.12 \\
0.25 \\
0.44 \\
0.16 \\
0.17\end{array}$ & $\begin{array}{l}0.62 \\
0.40 \\
0.34 \\
0.38 \\
0.40 \\
0.18 \\
0.49 \\
0.89 \\
0.94 \\
0.87\end{array}$ & & $\begin{array}{l}0.85 \\
0.88\end{array}$ \\
\hline $\begin{array}{l}2,4 \text {-dinitrophenylhydrazone } \\
\text { of levulic acid } \\
\text { pyruvic acid } \\
\text { a-ketoglutaric acid } \\
\text { oxaloacetic acid }\end{array}$ & & $\begin{array}{l}0.48 \\
0.41,0.61 \\
0.092 \\
0.14\end{array}$ & $\begin{array}{l}0.34 \\
0.06 \\
0.07\end{array}$ & \\
\hline $\begin{array}{l}\text { vulic acid } \\
\text { accinic acid } \\
\text { imaric acid } \\
\text { aleic acid } \\
\text { tric acid }\end{array}$ & $\begin{array}{l}0.18 \\
0.22\end{array}$ & & & $\begin{array}{l}0.76 \\
0.74 \\
0.81 \\
0.47 \\
0.35\end{array}$ \\
\hline
\end{tabular}

Solvent I; Benzene 2: Aceric acid 2: Dist water 1 II; $n$-Butanol 4: Ethanol 1: 1 $\mathrm{N}\left(\mathrm{NH}_{4}\right)_{2} \mathrm{CO}_{8}$ buffer 2 III ; Butanol 3 per cent $\mathrm{NH}_{3}$

IV; $n$-Butanol 4: Formic acid 1.5: Dist water 1.

of these compounds developed by different solvents. These values are the average of several experiments and pyruvate was generously shown to have two spots when developed with the solvent 2 .

The detectable concentration of related compounds.

As shown in Table III, $m$-HBA was detectalbe from 3 gamma by the Diazo reaction, GA was detectable from 3 gamma by alkalic $\mathrm{FeCl}_{3}$ solution, but from only 1 gamma by its specific blue fluourescence. PCA was detectable from 3 gamma with its green spot by $\mathrm{FeCl}_{3}$ solution. Keto acids were detectable from 1 gamma in the form of their 2,4-dinitrophenylhydrazone. In the detetion of fatty acids it was necessary to use at least 100 gamma of them for bromcresol-purple as an indicator.

Detection of aromatic compounds from stationary cultural broth.

$R_{F}$ values obtained from the each Fraction 1 of the cultural broth of the several strains developed by the solvent 1 are shown in Table IV. Since the spots, of which the $R_{F}$ value 
Table III. The Detectable Concentration of Related Compounds by SeVERal Reagents on PaPERchromatography

\begin{tabular}{|c|c|c|c|c|c|}
\hline & \multirow{2}{*}{$\begin{array}{c}\text { Concentration } \\
\text { in spoting } \\
(r)\end{array}$} & \multicolumn{4}{|c|}{ Detection } \\
\hline & & $\mathrm{FeCl}_{3}$ & $\begin{array}{c}\mathrm{FeCl}_{3} \\
+\mathrm{NH}_{4} \mathrm{OH}\end{array}$ & U.V. ray & $\begin{array}{l}\text { Diazo- } \\
\text { reaction }\end{array}$ \\
\hline gentisic acid & $\left\{\begin{array}{l}5 \\
3 \\
1\end{array}\right.$ & $\stackrel{+}{+}$ & $\begin{array}{l}+ \\
+ \\
-\end{array}$ & $\begin{array}{l}+ \\
t \\
+\end{array}$ & \\
\hline protocatechuic acid & $\begin{array}{l}5 \\
3 \\
1\end{array}$ & $\begin{array}{l}+ \\
+ \\
-\end{array}$ & $\begin{array}{l}+ \\
+ \\
-\end{array}$ & $\overline{-}$ & $\begin{array}{l}+ \\
+ \\
-\end{array}$ \\
\hline$m$-hydroxybenzoic acid & $\left\{\begin{array}{l}5 \\
3 \\
1\end{array}\right.$ & & & & $\begin{array}{l}+ \\
+ \\
-\end{array}$ \\
\hline
\end{tabular}

TABle IV. $R_{F}$ VAlues OF THE INTERMEDIATES OF $m$-HYDROXYBENZOIC ACID IN FRACTION 1 in Stationary Gulture

Strain

Micrococcus ureae $\mathrm{S}-4$

Ps. ovalis $\mathrm{S}-5$

Bact. sp. Ca-1

Bact. sp. A-10-2

Micrococcus varians $\mathrm{P}-10-7$

Ps. dacunhae G1-13

Ps. dacunhae $\mathrm{Gl}-7$

Ps. dacunhae $\mathrm{R}-10-2$

Ps. dacunhae A-6-3

Ps. dacunhae A-7-2

Ps. cruciviae P-8-2

$m$-hydroxybenzoic acid

gentisic acid

protocatechuic acid

developing solvent was the upper layer of a mixture of benzene 2, acetic acid 2, water 1 .

Control were prepared as acetone solution.

was about 0.52 gave a negative reaction with $\mathrm{FeCl}_{3}$ while by the Diazo reaction gave a clear reddish orange, this substance was considered to be $m$-HBA. The spot with a $R_{F}$ value of $0.24 \sim 0.25$ was proved to be GA, since their $R_{F}$ and specific color reaction were the same as the synthetic samples GA was detected from the cultural broth of the strains S-4, S-5, A-10-2, and P-10-7. The strains G1-7, G1-13, R-10-2, A-6-3, A-7-2 and P-8-2 produced spots which were identifical with PCA.
The spot with a $R_{F}$ value of 0.27 produced by strain $\mathrm{Ca}-1$ was most probablly GA due to its fluorescence and to the results of coloring reations, although the $R_{F}$ value of 0.27 also corresponded to $\beta$-resorcilic acid.

Detection of aromatic compounds from shaking culture broth.

Table $V$ shows the results of detection of the intermediate from shaking cultural broth. As well as in the stationary culture, GA was recognized in the cultural brothes of strains S-4, S-5, while PCA was detectable in those of strains G1-7, R-10-2 and P-8-2.

Summarizing the above results, as seen in Table VI, the same conclusion from the experiment with the sequential induction method was obtained. That is, $m$-HBA was oxidized via gentisic acid or protocatechuic acid according to bacterial strain, respectively.

Detection of keto acids.

As described above, the distinction between

TABLE V. $R_{F}$ VALUES OF THE INTERmediates of $m$-HydRoxybenzoIC ACID IN Fraction 1 IN SHaking GULTURE

\begin{tabular}{lll}
\multicolumn{1}{c}{ Strain } & \multicolumn{2}{c}{$R_{F}$ Value } \\
Micrococcus ureae S-4 & 0.51 & 0.25 \\
Ps. ovalis S-5 & 0.52 & 0.24 \\
Ps. dacunhae G1-7 & 0.57 & 0.12 \\
Ps. dacunhae R-10-2 & 0.52 & 0.11
\end{tabular}

Developing solvent was the upper layer of a mixture of Berzene 2, acetic acid 2, water 1. 
Table VI. Summarizing the Production of Gentisic ACID OR PRotocatechuIC ACID BY $m$-HYDROXYBENZOIC ACID ASSIMILATING BACTERIA Strain

Micrococcus ureae $\mathrm{S}-4$

Ps. ovalis S-5

Bact. sp. $\mathrm{Ca}-1$

Bact. sp. A-10-2

Micrococcus varians $\mathrm{P}-10-7$

Ps. dacunhae $\mathrm{Gl}-7$

Ps. dacunhae G1-13

Ps. dacunhae R-10-2

Ps. dacunhae A-6-3

Ps. dacunhae A-7-2

Ps. crucizial $\mathrm{P}-8-2$

$$
\begin{array}{cc}
\text { Gentisic } & \begin{array}{c}
\text { Protocatechuic } \\
\text { acid }
\end{array} \\
\text { acid }
\end{array}
$$

$+\quad-$

$+\quad-$

$+\quad-$

$+\quad-$

$+\quad-$

- +

- +

- +

- +

- +

- +

TABLE VII. $R_{F}$ VAlues of THE INTERMEdATES OF $m$-HYDROXYBENZOIC ACID IN FRACTION 3 IN SHAKING CULTURE

\begin{tabular}{ccccc}
$\begin{array}{c}\text { Time } \\
\text { (culture) }\end{array}$ & \multicolumn{2}{c}{ Ps. ovalis S-5 } & \multicolumn{2}{c}{ Ps. dacunhae G1-7 } \\
& Spot I & Spot II & Spot I & Spot II \\
2 & 0.12 & 0.46 & & \\
4 & 0.16 & 0.49 & 0.14 & \\
6 & 0.13 & 0.49 & 0.12 & \\
8 & 0.13 & 0.49 & 0.13 & \\
10 & 0.14 & 0.41 & 0.14 & 0.41 \\
12 & 0.17 & 0.47 & 0.21 & 0.50 \\
14 & 0.16 & 0.42 & 0.18 & 0.46 \\
16 & 0.16 & 0.44 & 0.18 & 0.48 \\
18 & 0.17 & 0.44 & 0.18 & 0.48 \\
24 & 0.16 & 0.44 & 0.21 & 0.44
\end{tabular}

Developing solvent was the upper layer of a mixture of $n^{\text {n }}$ butanol 4, ethanol 1, water 2 .

the strains having GA pathway and the other having the PCA pathway, was recognized. The detection of keto acids was carried out from incubation mixtures of Ps. ovalis S-5 and Ps. dacunhae G1-7. The former was oxidized $m$-HBA via $\mathrm{GA}$, the latter oxidized $m$-HBA via PCA. An amount of $20 \mathrm{ml}$ of samples was taken every 2 hours, and 2,4-dinitrophenylhydrazone was prepared and then developed in solvent 2 . As seen in Table VII, different acids were detected depending upon the bacterial strain. In the case of Ps. ovalis the composition of acids was constant irrespective of the time of culture. Spot 1 of the former $R_{F}$ value of 0.12 corresponds to $\alpha$-ketoglutaric acid but assumed an orangish red color which is quite different from that of 2,4-dinitrophenylhydrazone of $\alpha$ ketoglutaric acid. In the chromatogram of the mixture with the authentic $\alpha$-ketoglutaric acid, the keto acid in question gave different spots hence the possibility that this keto acid is $\alpha$ ketoglutaric acid was excluded. As for the spot 1 of $P$ s. dacunhae, from the $R_{F}$ value it seemed to be 2,4-dinitrophenylhydrazone of $\alpha$-ketoglutaric acid from paperchromatography mixture with the authentic samples. In the other case, spot 11 was not detectable between 2 to 8 hours' incubation, and was considered to be 2,4dinitrophehylhydrazone of pyruvate.

\section{DISCUSSION}

These results do not clearly indicate successive steps of the metabolic pathway of $m$-HBA. However, they agreed with the assay of sequential induction method, which concluded that two metapolic pathways exist in the oxidation of $m$-HBA and its pathways are specific by bacterial strain. Namely, the existence of a common precursor is considered in the induced enzyme formation between analogous compounds, but against one inducer the bacterial metabolic activity differs between bacterial strains. R. Y. Stanier and N. Tsuchida ${ }^{10}$ in bacterial metabolism of tryptophan, previously demonstrated that there were two pathways, one the aromatic path via anthranilic acid, the other the quinoline path via quinolic acid, but both pathways did not exist together in one strain.

The production of lower keto acids are intermediary steps to terminal oxidation as well as the metabolism of aromatic compounds investigated by S. Dagley ${ }^{11}$ and M. Isono ${ }^{12)}$. An unknown keto acid produced by $P$ s. ovalis S-5 is considered to be a direct intermediate cleavaging benzene ring of GA. As will described in the

10) R. Y. Stanier and M. Tsuchida, Biochem. J.. 58. 45 (1949).

11) S. Dagley, M.E. Fewster and F. C. Happold, Biochem. J. 63, 327 (1952)

12) M. Isono, J. Agr. Chem. Sor. Japan, 27, 260 (1953). 
latter report ${ }^{13}$, the present authors assumed 7 carbons diketo-dicarboxylic acid, probably fumarylpyruvic acid, from the results obtained by manometrical experiment of gentisic acid oxidase. Therefore, considering the spot of its hydrazone not having appeared in developing Fraction 3 from cultural broth, it seems that metabolic decomposition of it had already been carried out or decomposition during prolonged hot ether extraction and other treatment had occurred.

\section{SUMMARY}

Oxidation of $m$-HBA by the eleven bacterial strains which were able to metabolize this compound as a sole source of carbon was carried out. The cultural broths were examined by paperchromatography for detection of intermediates.

Gentisic acid was identified in the culture

13) S. Sugiyama, K. Yano, H. Tanaka and $K$. Arima. This Bulletin, in press. filtrate of the five strains, while protocatechuic acid by the remaining six strains. Protocatechuic acid was not detected in all the cultural broth of bacteria which belong to the gentisic acid path type, and vice versa.

Strains which possess the gentisic acid path were Pseudomonas ovalis (two strains), Micrococcus ureae, and an unidentified Bacterium and a strain of Aerobacter. Strains which have the protocatechuic acid path were Pseudomonas dacunhae (five strains) and Pseudomonas cruciviae.

An unknown keto acid was detected as its 2,4-dinitrophenylhydrazone from the incubation mixture of the resting cell of Pseudomonas ovalis S-5 and gentisic acid. This new keto acid was most probably the direct intermediate after the cleavage of gentisic acid.

Acknowledgement The authors wish to express their sincere thanks to Prof. Emeritus K. Sakaguchi for his continous guidance throughout this work. 